$11^{\text {th }}$ ICEEPSY 2020

The International Conference on Education and Educational Psychology

\title{
STORYTELLING FOR MORAL EDUCATION OF SCHOOLCHILDREN IN SELF-COGNITION CLASSROOM
}

\author{
Aigerim Mynbayeva (a)*, Nazgul Anarbek (b), Assel Nurgaliyeva (c) \\ *Corresponding author \\ (a) Al-Farabi Kazakh National University, al-Farabi av., 71, Almaty, Kazakhstan, \\ Aigerim.Mynbaeva@kaznu.kz
}

(b) Bobek National Scientific and Practical, Educational and Health Centre, Almaty, Kazakhstan

(c) School \#52, Almaty, Kazakhstan

\begin{abstract}
Storytelling is one of the central teaching strategies of the $21^{\text {st }}$ century applied in moral education. Research questions: What diagnostic tools to measure moral qualities may be recommended for Selfcognition teachers in classroom? How to diagnose risk group children based on their conscientiousness and what are the ways of applying storytelling in moral development? What are the changes in learners after using targeted storytelling? The purpose of this study is to develop targeted storytelling techniques for risk group children for curriculum-oriented moral education in Self-cognition classroom, to diagnose children for the purpose of curriculum development, and pilot-test the curriculum in classroom. The study involved $1026^{\text {th }}$ grade schoolchildren at Almaty based School 52 (aged 12). The following diagnostics tools were used: the Melnikov-Yampolsky Conscientiousness Scales, the Ilyin Method of Conscientiousness Analysis. According to the diagnosis, 32 learners (34.04\%) from the sample were assigned to the risk group as part of conscientiousness diagnostics. Based on the method developed, Selfcognition unit plan consisting of 4 lessons using storytelling has been designed. The specificity of the technique, its novelty lies in the identification of learner's problems and the selection of stories with an orientation towards the development of self-cognition value (Veracity, Right behavior, Non-violence, Peace, Love). Following the experiential work for the moral development on the basis of a special selfcognition curriculum, schoolchildren wrote essays and drew drawings. According to the learning outcomes, positive changes were observed in the schoolchildren.
\end{abstract}

2672-8141 (C) 2020 Published by European Publisher.

Keywords: Moral education, conscience, self-cognition lessons.

(C) The Author(s). This work is licensed under a Creative Commons Attribution-NonCommercial-NoDerivatives 4.0 International License (http://creativecommons.org/licenses/by-nc-nd/4.0/). 


\section{Introduction}

Matters of moral development of an individual have been constantly the focus of educational science. Since the inception of educational thought, a vast body of expertise and scientific understanding of individual's moral development have been accumulating. In Kazakhstani practice, since the country's independence, Self-cognition subject began its moving forward from the 2000s, and in 2010 a new Selfcognition subject was introduced into the school curriculum. It is focused on the development of the child's moral qualities and values. The core objective of the subject is to teach learners to see universal human values in their actions and deeds, moreover, to do new things, capturing them through the lens of the values of Love, Veracity, Right Behaviour, Non-Violence, Peace (inner harmony) (Mukazhanova \& Omarova, 2013). Thus, the school subject of 'Self-cognition' expands philosophical approaches in the development of the educational system. For instance, if traditional subjects are more focused on the building of knowledge, skills, and competencies of learners, this subject expands the foundations and academic achievements of learners by focusing on the meanings, values of schoolchildren, their good deeds and moral qualities, wholesome development of behavior strategies and images, motives, and lifestyle. For this subject, no grades are assigned to schoolchildren; mastery of the subject is assessed in 'pass/fail' format, driven by the virtually impossibility to design an assessment rubric for the acquisition of values. Therefore, teachers have to seek for new ways of how to stimulate children's interest in the subject, in the moral development of the 'self' from an early age, at a transitional age, in youth. Selfcognition subject is of integrated nature and it called a metasubject. Earlier we wrote (Mynbayeva et al., 2019) that integrated subjects are also taught in other countries, for instance, in South Korea, integrated lessons of 'Proper life', 'Pleasant life', 'Smart life' (Pak Su Chin, 2007), in Japan there is a Moral Education course (Kozachina, 2018) and others. In our opinion, Self-cognition subject is akin to these oriental practices, moreover, by its name 'Self-Cognition' focuses on the development of individual's 'Self-concept'

Since it is a new subject in educational practices, it taps into innovative teaching techniques and strategies. The school lesson includes the following phases (Mukazhanova \& Omarova, 2013; Mynbayeva et al., 2016): shaping a positive attitude, delivering lesson quotes, conversation or storytelling, creative and group work activities, singing songs, etc.

\section{Literature review}

\subsection{Morality, spirituality and moral education theories}

Grigorovich (2003) defines morality as a personality trait that combines such qualities and properties as kindness, decency, discipline, collectivism". Spirituality and morality demonstrate concurrent relations, so it may be difficult to clearly separate these concepts. For instance, Petrakova $(1999,2016)$ believes that there exists a connection between the concepts of 'spirituality' and 'morality': 'Norms and principles of morality are the facets of spirituality. If spirituality characterizes the higher, 'vertical' aspirations of an individual, then morality is the domain of 'horizontal' aspirations: the relations with others and society. That is, morality is stemming from spirituality being its extrinsic manifestation. In pedagogical practices, spirituality may be defined as a manifestation of 'the humane in a human'. 
Having reviewed the literature, we operationalized the concepts as follows: morality means the ability to autonomously make the correct moral choice, to subordinate ones deeds and behavior to it, being aware of the responsibility to people; spirituality means an internal state, humane feelings and emotions that urge an individual to commit moral deeds.

Spiritual and moral qualities of an individual, (1) according to Suholentseva (2013), are a set of accepted and moral norms well acquired by an individual, principles and rules that, under the influence of arising humane feelings, are applied voluntarily and appropriately; according to Sopova (2014), value characteristics of an individual orientated towards the self- (self-education, self-improvement), marked by a moral dominant, expressing consistently positive attitudes towards the world, others and oneself, according to Manerko (2011), socially significant (value-based) characteristics (traits) of the spiritual world, as well as behavior, communication and activities, marked by a moral dominant and allowing to realize one's inner potential, status and prosocial role as a citizen and patriot of the country and as a defender of one's Fatherland Following the review, let us clarify the definition as follows 'the spiritual and moral qualities of an individual are the personal, value-based and socially significant traits of an individual that determine his/her Right behavior in society, a positive attitude towards others, oneself, expressed in the development of moral norms and principles, the aspiration for spiritual selfdevelopment'

In pedagogical thought and science, there exist different traditions and theories of moral, spiritual education, and human decency.

The reflection of moral education theories in the European tradition may be found in the works of Comenius, Kant, Herbert and others. Analysis of the Comenius's method of moral education allows us to emphasize the focus on the development of the underlying 'cardinal' virtues of 'wisdom, moderation, courage and justice'. Such understanding of the basic virtues was historically laid down in Ancient Greece. To strengthen and cement them in an individual according to Comenius (2003), 'personal example', 'positive environment', 'labor education' may be used.

One proponent of pedagogical science, Herbart suggested that moral education should take place through the formation of discipline in a child (Konstantinov, 1981). As Xiaoman (2006) points out, moral education is the essence of education and any true teaching activities have educational meaning, that is, the aim of them is to cultivate one's mind. The primary goal is to shape human morals (Dzhurinsky, 2016). In the western tradition of the twentieth century, Colbert's theories of moral development, selfdetermination theory by Eisenberg and others (Kaur,2015) are known. The pedagogical concepts consider the axiological and value-semantic approach with the 'Golden rule of morality', going back to the ancient Greek views of philosophers about virtues. Medves (2018) summarizes the triad of key ideas behind moral education as follows: (1)'The Golden Rule' - 'Treat others as you want to be treated', or 'do not treat others in ways that you would not like to be treated', (2) Aristotle's Doctrine of the Mean, (3) Kant's Categorical Imperative - 'act only according to that maxim whereby you can, at the same time, will that it should become a universal'; or 'act in such a way that you treat humanity, whether in your own person or in the person of any other, never merely as a means to an end, but always at the same time as an end'. 
In the domestic tradition, we will focus on only two concepts. Eastern philosophers, adhering to the ancient Greek ones, singled out the moral virtues of society and human. Abu Nasr al-Farabi (870-950) in the Middle Ages (9-10th century) wrote a treatise on the 'virtuous city', where would the virtuous people live. Virtue, according to Abu Nasr al-Farabi (2019), is a piece of matter. Al-Farabi emphasized the importance of upbringing and education for an individual him/herself, for the moral and intellectual development, in order to become a happy person ('The Attainment of Happiness'). According to Abu Nasr al-Farabi (2019), the virtues are of two kinds, ethical and rational. The rational virtues are the virtues of the rational part, such as wisdom, intellect, cleverness, readiness of wit, excellence of understanding. The ethical virtues are the virtues if the appetitive part, such as temperance, bravery, generosity, justice. In his works, Abu Nasr al-Farabi (2019) adopts the Aristotelian concept of the "mean" (translated in some sources as 'Aristotle's The Doctrine of the Mean) or the 'middle way', mean states of the soul. Hence the idea of the value of Moderation in many qualities, 'unity-in- contradiction', ambivalence of the 'good and evil' and the search for a golden mean is obvious. In order to find the middle it is important for a human to think, engage in a cognitive process, since it is the key to the internal labor of an individual at him/herself. Here is what Abu Nasr al-Farabi said: "actions which are good deeds are the moderate, mean actions between two extremes, both of which are bad, the one excess and the other defect. And similarly the virtues, for they are mean states and qualities of the soul between two other states, both of which are vices, the one excessive and the other defective (al-Farabi, 1961, p.34, as cited in Abu Nasr al-Farabi, 2019). "Generosity is a mean between parsimony and prodigality. Bravery is a mean between rashness and cowardice. Wit is a mean in jesting and play and so forth between imprudence and unruliness, and severity. Courtesy is a mean between haughtiness, boasting and swagger. Forbearance is a mean between excessive anger, and the state in which one never becomes angry at anything. Friendliness is a mean between odiousness and flattery. And so on" (al-Farabi, 1952, p. 101, as cited in Abu Nasr al-Farabi, 2019).

Currently, the school uses 'Self-cognition' as the concept of moral and spiritual education, developed under the leadership of Nazarbayeva. A full presentation of the conceptual foundations may be found in the works of Mukazhanova and Omarova (2013, 2016), Omarova et al. (2016). The concept highlights the universal values behind 'Self-cognition', namely, 'Veracity' (Veracity is an understanding of the unity of all that exists, acceptance of reality as it is), 'Love' (an individual's positive energy, hence his/her positive choice), 'Right behavior' (to awaken the ability inherent in each individual to discern and hear the voice of Conscience), 'Peace' (to control feelings one should first calm the mind), 'Nonviolence' (to try not to harm anyone; understand that all creatures have feelings and the right to life) (Mukazhanova \& Omarova, 2013). Let us now dwell on the concept of a wholesome individual and the identification of facets or levels in it (Omarova et al., 2016) (Figure 01). In each individual, in his/her Self-concept, one can distinguish 'the bodily self', the 'emotional self', the 'mental self' (knowledge of an individual, or as we say, his/her educational attainment), the 'rational self' (level of reason, reflections of an individual, ethical distinctions), the 'spiritual self'. Let us explain that the level of intelligence, as emphasized by the authors, in the case of an individual's inner work, value work on oneself, becomes the key in an individual's movement towards spirituality (the key turns 'upwards'), or with the predominance of his egocentric features (the key turns 'downwards') - regression. The task of modern teachers, 
including Self-cognition teachers, is to nourish not only the bodily, emotional, mental facets of an individual, as well as to activate the 'level of reflection/discrimination', in other words, internal spiritual labor, with a focus on the universal human values of Veracity, Love, Right behavior, Peace, Nonviolence.

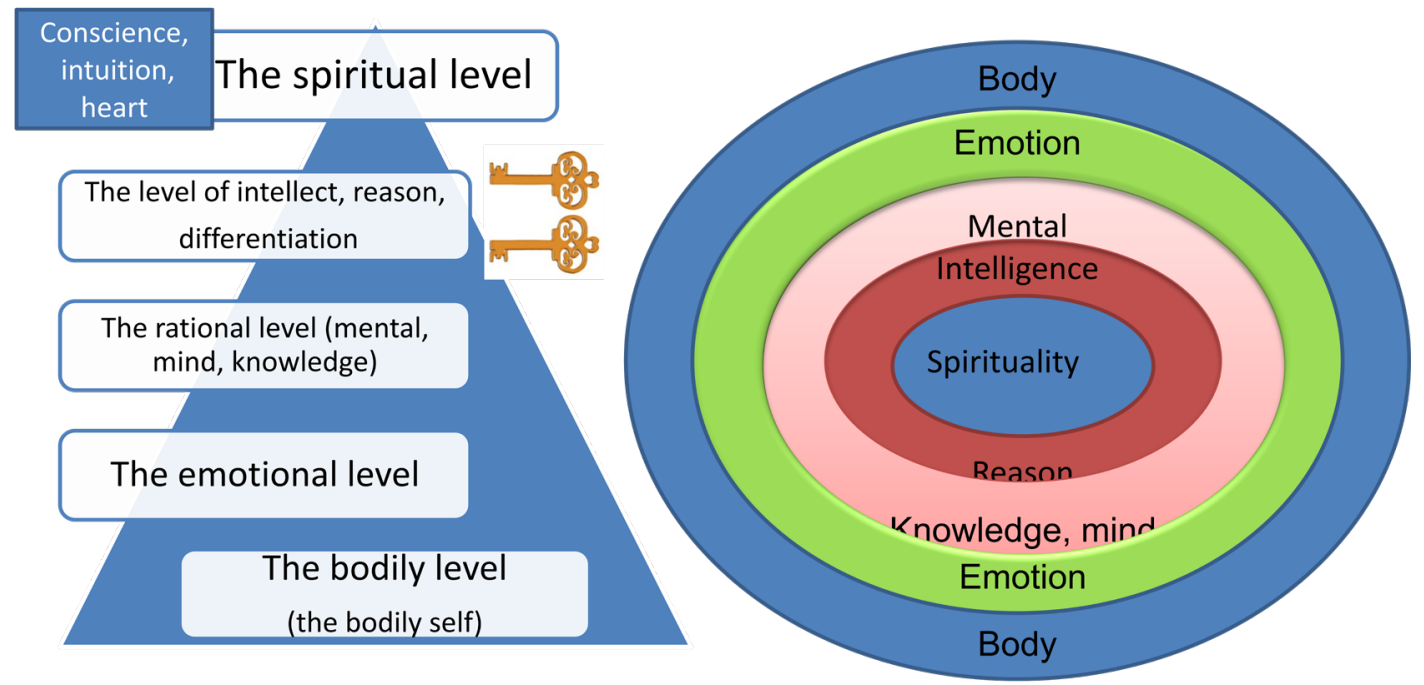

Bobek National Scientific and Practical, Educational and Health Self-cognition Centre

Figure 01. Concept of an individual (Bobek National Scientific and Practical, Educational and Health Centre, Self-cognition subject)

In our opinion, this theory has intersection points with many theories, including Johann Herbart's theory of moral education. Analysis and comparison of Herbart's concepts and the 'levels of individual's self' allows getting a better idea of the differences in the 'mental educational attainment' and the 'level of value differentiation'. That is, an intelligent person, an educated person knows what it is to manage knowledge, think, compare, analyze, and generalize it. These are the analytical skills and the work of the 'brain'. At a more advanced level, a stepping-stone to the spiritual level with the help of intellect, or reflection, is to operate with value-based thinking with the inclusion of the 'heart'. Conventionally, we can say that Herbart puts precisely morality higher than education itself, in other words, than learning, in the modern sense - education, the amount of learned, internalized knowledge. However, advancement to spirituality requires self-awareness and a value-oriented mind.

Storytelling and conversations are viewed as the tools for value-based reflection in Self-cognition classroom used in the school. The subject's technique encompasses active discussion of the stories told, asking open-ended questions.

\subsection{Storytelling and narrative theories}

The study of the concept of storytelling has demonstrated that the term is an interdisciplinary construct, used as a modern tool in many sciences and operational domains. In addition to pedagogy and psychology, it is especially actively used in marketing, management (establishing organizational culture 
in firms), journalism, cinematography, political science, etc. Storytelling - (1) according to Todorova (2014), is understood as a 'modern form of 'telling stories'- a communication, pop and marketing strategy, which employs the entire potential of speaking'; (2) according to Novichkova and Vokresenskaya (2014), organizational storytelling is a management tool that is used to understand, interpret and disseminate values, norms, rules and principles of organizational culture through the use of corporate stories, myths, legends, (3) according to Starichenko (2015), storytelling is 'a marketing technique that uses media potential to convey information and transfer meaning through storytelling, in order to grab attention from the first second and keep it throughout the story, making the reader or viewer sympathize with the protagonist of the story, and thus convey the key message'. In our study, we relied on the definition of Fedorova and Barcheva (2017) which posits that 'storytelling is a pedagogical technique, built on the use of stories with a specific structure and an interesting hero, which is aimed at resolving pedagogical issues of upbringing, development and education'. Based on the analysis of definitions, we emphasize that the 'key' to discovering the essence of storytelling is the terms of 'values' and 'meanings'.

In fact, storytelling is a creative process, as it is associated with the artistic word, the art of composing stories and sharing them. We emphasize that while storytelling is about telling or retelling famous stories, it is also about inventing new ones. Most often, it is obvious that new stories will reflect the elements of an individual's personal experience or imagination.

Storytelling in didactics is a traditional teaching strategy, according to Podlasy (1996); it is referred to verbal teaching strategies, which has emerged since ancient times. At the same time, storytelling as an innovative technique is included in the UNESCO recommendations in 2010 as the leading educational tool of the $21^{\text {st }}$ century (Teaching and Learning for a Sustainable Future, 2018). What is the difference between the strategies? In our opinion, the difference lies with the skill and technique of creating new stories. To do this, the learners are explained the basic plot structure: 'introduction - climax resolution', the seven basic plots by Christopher Booker, and types of storytelling. For instance, the following types of storytelling are distinguished: classic, active, and digital. The emergence of digital storytelling also adds a new feature to this contemporary teaching method. For the digital generation of learners, given their clip thinking, images, visual images of the created stories are crucial; therefore, a video sequence of a story is of importance.

We also focus on the essence of modern scientific approaches to the creation of stories. Composing stories as storytelling is subject to different theories and concepts, in particular, the narrative approach and narrative psychology, Mead's theory of social interactionism, Jung's theory of archetypes, and others.

The narrative approach. Polkinghorne (1988) distinguished between key meanings of the narrative in social sciences and narrative in a broader sense is any written or oral narrative, and narrative in the narrow sense is a scheme for organizing experience (for instance, Labov's model) (Johnstone, 2016) that includes certain components. More often than not, the word 'narrative' is used simply as a synonym for the word 'story' or 'short story' (Barskiy, 2017). From the point of view of narrative psychology, 'an individual is treated as a text' (Trotsuk, 2004), in other words, individuals produce abundant texts over the lifetime - oral, written, internal or reflected on paper, electronic media, etc. Narrative is a story, with 
the help of which the subject constructs his/her self and maintains his/her integrity (Berger \& Luckmann, 1995).

Kadyrova (2012) summarized the narrative essence of storytelling, the main theses of which are given in this article: '1) Reality is shaped by language and transmitted in narratives that are told by people to one another. The subject constructs his/herself and maintains his/her identity with the help of narratives, relying on the discourses prevailing in the culture, which are considered as texts obtained by interaction. 2) Narrative is a logically coherent, time-ordered text that helps organize the subject's personal experience. 3) Narrative analysis allows displaying the psychological reality hidden in the text. The complex chain of listener-reader interactions and the text ends with the construction of a new narrative'.

Another concept of symbolic interactionalism or the 'generalized other' by George Herbert Mead overlaps with the concept of the Cooley's 'looking glass self' (Barskiy, 2017). An individual interacting with others in a group, as if taking their place, sees himself through their eyes and assesses him/herself as a whole. An individual also assesses his/her individual properties and then acts in accordance with the presented estimates of the 'generalized other'. In fact, we can say that others are 'looking glasses' that help us gain a better idea, reflect or reveal who we are. This concept confronts us with the concepts of projection, transference and countertransference, i.e. projective psychology. Cognition of an individual is being shaped through conversations, discussions, through visual, mental, verbal comparison of oneself with others...

The next theory is related to archetypes. The archetypes are universal innate mental constructions of an individual that make up the content of the common human 'collective unconscious' and spontaneously inform human thought and behavior (Jung, 2020, 2019). The self is the most salient archetype in Jung's theory. The self is the core of an individual around which all other elements are organized. It is when the integration of all aspects of the soul is accomplished; an individual may feel unity, harmony and integrity. Thus, by telling a story, a learner not only build knowledge, but more importantly, conveys and interprets meanings and values, behavioral strategies, lifestyle that are important from the standpoint of personal experience, and through them advances to his/her selfactualization. In our opinion, the work with human values and meanings is also associated with the development of intrapersonal and interpersonal intelligence in schoolchildren according to the typology of Gardner. It is obvious that while Self-cognition subject contributes to moral education, it is also important in the enhancement of interpersonal and intrapersonal skills. The task of the teacher is to create conditions for the positive self-actualization of an individual.

\section{Problem Statement}

Self-cognition subject is focused on moral development of an individual, its philosophical construct is secular and connected with the foundations of humanistic psychology of Frankl, Rogers, Kohlberg (as cited in Mukazhanova \& Omarova, 2016), humane pedagogy of Amanoshvili (as cited in Omarova et al., 2016); value orientations of ethnopedagogy, etc. This study continued investigating new approaches and methods of children's moral education and development. One of the many goals a teacher should accomplish is to diagnose situations, to identify potential value deviations, distortions, and even 
value deformations in the development of a child for his/her full positive self-actualization. Hence, the following questions arose: Are there available tools to measure moral qualities in a child that can be applied by teachers? How can storytelling be used in a targeted manner? Let us now coherently state the research questions.

\section{Research Questions}

What tools for the diagnostics of spiritual and moral qualities may be recommended for Selfcognition in classroom? How should a conscientiousness-based diagnostics of the risk group children be conducted and how storytelling can be applied in moral development? How is storytelling different from traditional narratives? What are the changes in learners after using targeted storytelling?

\section{Purpose of the Study}

The purpose of this study is to develop targeted storytelling techniques for risk group children for curriculum-oriented moral education in Self-cognition classroom, diagnose children for curriculum development, and pilot-test school curriculum. Research objectives are as follows: (1) diagnostics of spiritual and moral qualities, namely conscientiousness; (2) targeted identification of schoolchildren's problems and determination of the corresponding value of Self-cognition subject for moral development; (3) curriculum design incorporating storytelling.

\section{Research Methods}

Research design included two parts: theoretical and practical. In the first part, we analyzed the definitions of the constructs of 'morality' and 'spirituality', theory of moral education, examined theoretical underpinnings of storytelling for subsequent use in moral education, developed a step-by-step technique or designed a process of shaping the spiritual and moral qualities in 'risk group' learners. In the second part, the spiritual and moral attainment in schoolchildren, $6^{\text {th }}$ grade learners, was diagnosed using the Melnikov-Yampolsky Conscientiousness Scales (Ilyin, 2016), the Ilyin Method of Conscientiousness Analysis (Ilyin, 2001); designed a storytelling curriculum for Self-cognition lessons in accordance with the 'risky responses' of the learners, which was subsequently tested in classroom.

The Conscientiousness Scales are designed to assess the degree of respect for moral standards and ethical requirements. Individuals with a high value of conscientiousness factor are characterized by the traits affecting their motivated behavior, such as a sense of responsibility, conscientiousness, strength of moral principles. How they behave is guided by a sense of duty, they strictly observe ethical standards; always strive to conform to social expectations, whereby their high conscientiousness is usually combined with good self-control. The second applied tool is the Method of Conscientiousness Analysis developed by Ilyin, which is aimed at identifying an individual's propensity to feel guilty. When drafting the questionnaire, we were borrowed some constructs from the Bass-Darkie method (indicator of sense of guilt). To mask the purpose of the survey, the questionnaire contained neutral constructs. The instructions for both diagnostics are the same: a number of constructs are proposed, if one agrees with construct, '+' 
sign is put next to it, if disagrees, '-' sign is put. 102 learners of $6^{\text {th }}$ grade at Almaty based school No. 52 took part in the diagnostics.

\section{Findings}

Questioning how spiritual and moral qualities may be diagnosed, we found several diagnostic tests in the psychological literature. For instance, in Ilyin's (2001, 2016) books, 'The Psychology of Conscience, 'Emotions and feelings', The Psychology of Help, Altruism', several conscientiousness tests were given. We have chosen the methods that are best suited for $6^{\text {th }}$ grade schoolchildren. We chose the Melnikov-Yampolsky Conscientiousness Scales (a 14-item questionnaire), the Ilyin Method of Conscientiousness Analysis (a 21-item questionnaire).

The experimental work included three stages: diagnostic, formative, and control (Isaeva \& Taubayeva,2000). The diagnostic study was carried out at Almaty-based School No. 52 with $1026^{\text {th }}$ grade learners, aged 12. Individuals with a high value of conscientiousness factor are characterized by such traits of an individual that affect the motivation of behavior, such as a sense of responsibility, conscientiousness, strength of moral principles. The results for the two tests are presented in Table 01 below.

Table 01. The results of the Melnikov-Yampolsky Conscientiousness Scales, the Ilyin Method of Conscientiousness Analysis

\begin{tabular}{|c|c|c|c|}
\hline Conscie & ntiousnes: & (Melniko & \\
\hline & Spiritual & oral attair & \\
\hline Giatie & High & Average & Low \\
\hline $6^{\prime} \mathrm{A}^{\prime}$ & 9 & 9 & 1 \\
\hline 6 'B' & 9 & 3 & 5 \\
\hline $6^{\prime} C^{\prime}$ & 21 & 5 & 0 \\
\hline 6 'D' & 6 & 7 & 8 \\
\hline 6 'E’ & 4 & 10 & 5 \\
\hline Total: & 49 & 34 & 19 \\
\hline Method & of Consci & ness Anal & \\
\hline & Spiritual & oral attair & \\
\hline Grade & $\begin{array}{l}\text { Above } \\
\text { average }\end{array}$ & Average & Below average \\
\hline $6^{\prime} \mathrm{A}^{\prime}$ & 12 & 6 & 1 \\
\hline 6 'B' & 9 & 4 & 4 \\
\hline $6^{\prime} C^{\prime}$ & 17 & 5 & 4 \\
\hline 6 'D' & 13 & 3 & 5 \\
\hline $6^{\prime} \mathrm{E}$ ' & 8 & 6 & 5 \\
\hline Total: & 59 & 24 & 19 \\
\hline
\end{tabular}

Following discussion with an expert group consisting of the scholars of the department, we have developed a single scale (Table 02), in which the 'low' level obtained at least in one test assigns the overall low level. The learners, who received a low-level result, were conditionally attributed to 'risk group' schoolchildren, since their results ought to be monitored. 
Selection and peer-review under responsibility of the Organizing Committee of the conference

$2672-8141$

Table 02. The scale for assessing the spiritual and moral attainment for this study

\begin{tabular}{|c|c|c|c|}
\hline \multicolumn{2}{|c|}{$\begin{array}{l}\text { Criteria for the assessment of spiritual and } \\
\text { moral attainment }\end{array}$} & \multirow{2}{*}{$\begin{array}{l}\text { Evaluation of the spiritual and } \\
\text { moral attainment for this } \\
\text { research }\end{array}$} & \multirow{2}{*}{$\begin{array}{l}\text { 'Risk group' } \\
\text { category }\end{array}$} \\
\hline $\begin{array}{l}\text { Conscientiousness } \\
\text { Scales }\end{array}$ & $\begin{array}{l}\text { Method of } \\
\text { Conscientiousness } \\
\text { Analysis }\end{array}$ & & \\
\hline High & High & $\operatorname{High}(\mathrm{H})$ & - \\
\hline High & Average & \multirow{3}{*}{ Average (A) } & \multirow{3}{*}{-} \\
\hline Average & High & & \\
\hline Average & Average & & \\
\hline Low & High & \multirow{5}{*}{ Low (L) } & \multirow{5}{*}{+} \\
\hline Low & Average & & \\
\hline High & Low & & \\
\hline Average & Low & & \\
\hline Low & Low & & \\
\hline
\end{tabular}

Of 102 of sixth grade learners on the overall scale of the two methods, 32 learners can be identified as 'risk group' children (Table 03). This represents $34.04 \%$ of the learners.

Table 03. Results by grade

\begin{tabular}{|l|l|l|}
\hline Grade & Total number of children & Risk group category \\
\hline 6 A & 19 & 2 \\
\hline 6 B & 17 & 6 \\
\hline 6 C & 26 & 4 \\
\hline 6 D & 21 & 11 \\
\hline 6 E & 19 & 9 \\
\hline Total & 102 & $32(34,04 \%)$ \\
\hline
\end{tabular}

Of 102 people showing low spiritual and moral attainment, $6.25 \%$ were in 6 ' $\mathrm{A}$ ', $18.75 \%$ in 6 ' $\mathrm{B}$ ', $12.5 \%$ in 6 ' $\mathrm{C}$ ', $34.375 \%$ in 6 ' $\mathrm{D}$ ', $28.125 \%$ in 6 ' $\mathrm{E}$ '. Thus, the largest number of 'risk group' learners were found in 6 'D' (Figure 02).

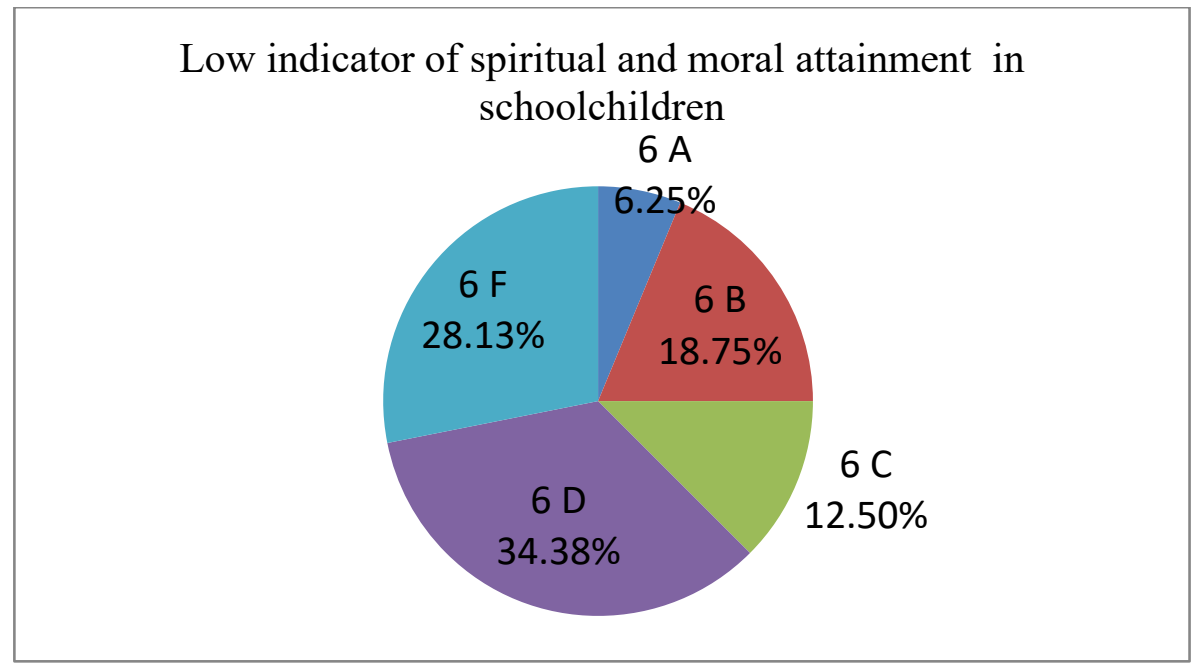

Figure 02. Risk group' schoolchildren according to the results obtained using the methods developed by Melnikov-Yampolsky and Ilyin 
In the course of treating the results of the Conscientiousness Scales diagnostics, we have revealed that the largest number of learners with low indicators of spiritual and moral attainment were in 6 ' $D$ ' grade, respectively, a formative stage ought to be carried out there using our technique.

To work with the schoolchildren, we have developed a targeted storytelling procedure including organizing the process of shaping the spiritual and moral qualities in 'risk group' learners, as summarized in Table 04.

Table 04. Designing the targeted storytelling technique

\begin{tabular}{|c|c|}
\hline Component & Description \\
\hline Aim: & $\begin{array}{l}\text { Shaping spiritual and moral qualities in 'risk group' learners using the storytelling } \\
\text { procedure in Self-cognition classroom }\end{array}$ \\
\hline $\begin{array}{l}\text { Diagnostic } \\
\text { toolkit: }\end{array}$ & $\begin{array}{l}\text { - to diagnose the spiritual and moral attainment in learners; } \\
\text { - to analyze and process diagnostic results; } \\
\text { - based on the diagnostics results, select a targeted teaching strategy; } \\
\text { - to develop a self-cognition lesson outline using the storytelling procedure. } \\
\text { The Melnikov-Yampolsky Conscientiousness Scales and the Ilyin Method of } \\
\text { Conscientiousness Analysis }\end{array}$ \\
\hline $\begin{array}{l}\text { Procedures } \\
\text { and } \\
\text { techniques }\end{array}$ & $\begin{array}{l}\text { Step 1. Diagnosing the spiritual and moral attainment in learners using the methods } \\
\text { of Melnikov-Yampolsky and Ilyin; } \\
\text { Step 2. Identifying the learners attributed to 'risk group' children according the } \\
\text { diagnostics results; Treatment of diagnostic results and analysis of learner responses. } \\
\text { Step 3. Identifying the most 'risky responses', 'problematic areas' in 'risk group' } \\
\text { learners, and selection of stories for the design of Self-Cognition material; } \\
\text { Step 4. Developing and selecting digital storytelling form. Conducting a sequence of } \\
\text { Self-Cognition lessons using the storytelling procedure and digital storytelling } \\
\text { forms for the 'risk group' leaners. In case of low efficiency for a particular child, one- } \\
\text { to-one work with such learners ought to be strengthened; } \\
\text { Step 5. Follow up on the spiritual and moral attainment in learners. Revealing the } \\
\text { changes in the spiritual and moral attainment in learners pre- and post lessons using } \\
\text { the storytelling procedure. Analysis of the results. Reflection }\end{array}$ \\
\hline
\end{tabular}

Having analyzed the responses of the learners, and having determined the 'risky responses', we have developed Self-cognition lessons using storytelling (Table 04).

According to the Ilyin Method of Conscientiousness Analysis, we attribute the following most frequent responses of the learners to the 'risky responses', for instance:

1. As a child, when I hurt someone or grabbed toys from others, I have never looked back on it. (positive answer)

2. When I do wrong, I don't tend to suffer from pricks of conscience (negative answer)

3. I end up doing a lot of things that often make me feel regretful (positive answer)

For such 'risky responses' of the learners, we have specifically developed some techniques to be used in Self-cognition classroom, selected the following stories 'The wisdom of the neighbor', 'Who is tenderer?', 'The coin', 'The heavy load of resentment', prepared open-ended questions, and used various storytelling forms. It should be noted, that the stories were selected through the prism of Self-cognition value, as presented in Table 05. 
Table 05. Storytelling-based Self-cognition curriculum addressing the 'risky responses' of the learner

\begin{tabular}{|c|c|c|c|c|c|}
\hline $\begin{array}{l}\text { Risky } \\
\text { response/nu } \\
\text { mber }\end{array}$ & $\begin{array}{l}\text { Lesson } \\
\text { No. }\end{array}$ & Topic & Value/Qualities & $\begin{array}{l}\text { Stories/sto } \\
\text { rytelling }\end{array}$ & Discussion questions \\
\hline $\begin{array}{l}\text { As a child } \\
\text { when I hurt } \\
\text { someone or } \\
\text { grabbed toys } \\
\text { from others, } \\
\text { I have never } \\
\text { looked back } \\
\text { on it. }\end{array}$ & 1 & $\begin{array}{l}\text { In-class } \\
\text { relations } \\
\text { hips }\end{array}$ & $\begin{array}{l}\text { Right behavior } \\
\text { good manners, } \\
\text { politeness, } \\
\text { teamwork, } \\
\text { fairness }\end{array}$ & $\begin{array}{l}\text { The } \\
\text { wisdom of } \\
\text { the } \\
\text { neighbor } \\
\text { (+video } \\
\text { clip) }\end{array}$ & $\begin{array}{l}\text { Why does an individual respond } \\
\text { to the bad deeds of the envious } \\
\text { neighbor with kindness and } \\
\text { friendliness? } \\
\text { How do you understand the } \\
\text { expression in any situation, } \\
\text { remain human'? } \\
\text { Where do you see the meaning of } \\
\text { the expression 'poverty of spirit'? } \\
\text { Tell us, have you ever } \\
\text { experienced similar situations? } \\
\text { What would you do in the place } \\
\text { of the second neighbor? } \\
\text { Why is it so important to do good } \\
\text { in life? }\end{array}$ \\
\hline $\begin{array}{l}\text { When I do } \\
\text { wrong, I } \\
\text { don't tend to } \\
\text { suffer from } \\
\text { pricks of } \\
\text { conscience }\end{array}$ & 2 & $\begin{array}{l}\text { The } \\
\text { aspiratio } \\
\mathrm{n} \text { to } \\
\text { beauty }\end{array}$ & $\begin{array}{l}\text { Inner peace } \\
\text { patience, ability } \\
\text { to concentrate, } \\
\text { positive } \\
\text { thinking, } \\
\text { tranquility }\end{array}$ & $\begin{array}{l}\text { Who is } \\
\text { tenderer? }\end{array}$ & $\begin{array}{l}\text { Why do you think the youngest } \\
\text { daughter, despite the fact that her } \\
\text { father failed to notice her, did not } \\
\text { stop taking care of him? } \\
\text { How did the father determine } \\
\text { which of the daughters is } \\
\text { tenderer? Can we say that the } \\
\text { eldest daughter is aware of } \\
\text { everything, that she is feels pricks } \\
\text { of conscience? } \\
\text { Why? } \\
\text { Tell us how else in everyday life } \\
\text { you can show your love to the } \\
\text { loved ones? }\end{array}$ \\
\hline $\begin{array}{l}\text { I get } \\
\text { frustrated } \\
\text { over doing } \\
\text { little for my } \\
\text { parents }\end{array}$ & 3 & $\begin{array}{l}\text { Family } \\
\text { ties }\end{array}$ & $\begin{array}{l}\text { Love } \\
\text { friendliness, } \\
\text { caring for loved } \\
\text { ones, } \\
\text { selflessness, } \\
\text { sensitivity, } \\
\text { generosity, } \\
\text { selfless service }\end{array}$ & The Coin & $\begin{array}{l}\text { Why do you think, in the end, } \\
\text { there is only one coin left in the } \\
\text { boy's wallet? } \\
\text { Why is it so important in life not } \\
\text { to give up on one's dreams? } \\
\text { What is the true wisdom of the } \\
\text { story? } \\
\text { Think of a life situation when the } \\
\text { good you did came back to you, } \\
\text { like the law of the boomerang? }\end{array}$ \\
\hline $\begin{array}{l}\text { I end up } \\
\text { doing a lot } \\
\text { of things } \\
\text { that often } \\
\text { make me } \\
\text { feel } \\
\text { regretful }\end{array}$ & 4 & $\begin{array}{l}\text { Living in } \\
\text { peace } \\
\text { with } \\
\text { others }\end{array}$ & $\begin{array}{l}\text { Non-violence } \\
\text { friendliness, } \\
\text { justice, not } \\
\text { hurting others } \\
\text { by thought, } \\
\text { word or deed, } \\
\text { unity }\end{array}$ & $\begin{array}{l}\text { The heavy } \\
\text { load of } \\
\text { resentment } \\
\text { (+ video) }\end{array}$ & $\begin{array}{l}\text { What qualities should an } \\
\text { individual have to be able to } \\
\text { forgive? } \\
\text { Think of a situation in your life } \\
\text { that left you with a heavy heart } \\
\text { because of resentment? How did } \\
\text { you handle it? }\end{array}$ \\
\hline
\end{tabular}

After four lessons, the learners were assigned with a creative task. 
At the control stage, in order to detect the changes in the spiritual and moral attainment in 'risk group' learners, the task was to write an essay or make illustrations on the following topics: The beauty of the human soul'; 'My household choirs'.

Having examined the creative works of the learners, we assessed them by distributing across three levels of spiritual and moral attainment, namely, high, average, and low level. According to the data obtained, in 9 out of 11 learners the spiritual and moral attainment has increased from low to average level, which makes $81.81 \%$ of the total number of 'risk group' learners of a particular grade (Figure 03).

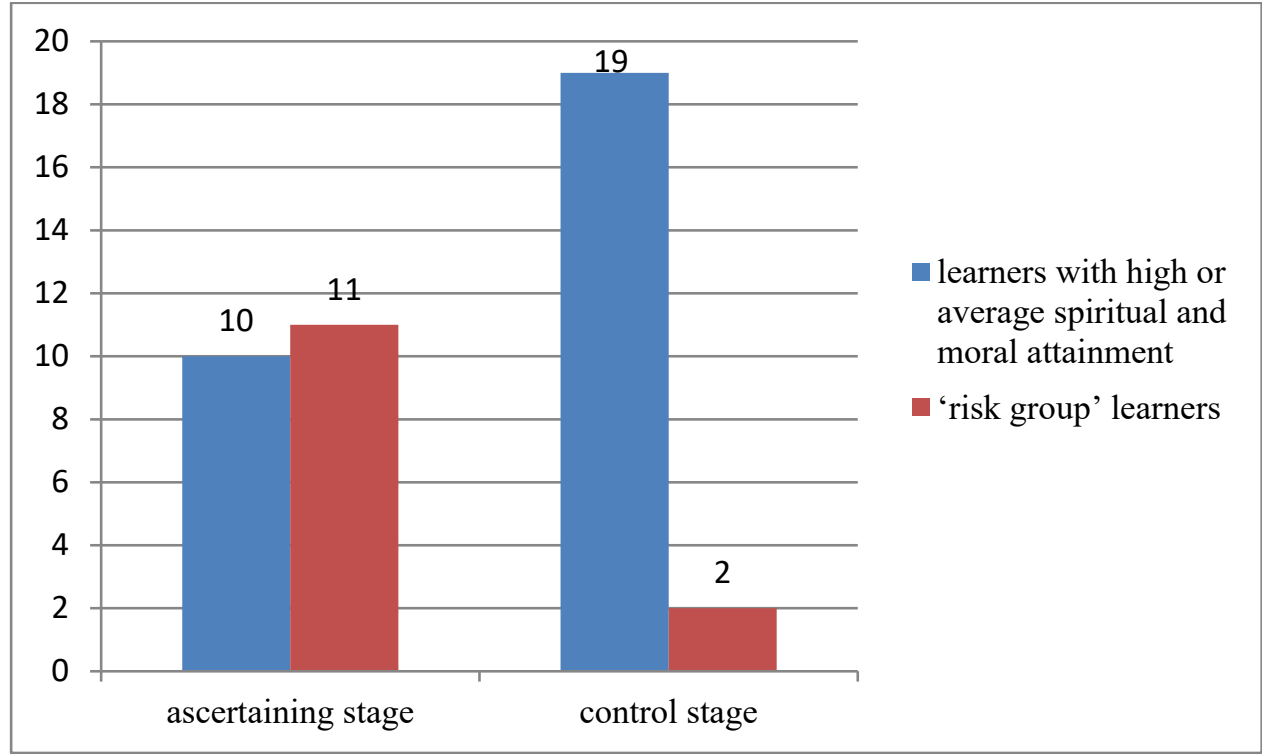

Figure 03. Changes in the spiritual and moral attainment in learners of 6 ' $D$ ' grade of the 'risk group' category

Below are some excerpts from the creative works of 'risk group' learners, the moral attainment of which, at the control stage, has been estimated as 'average' and 'high' (table 06).

Table 06. Some excerpts from the creative works of 'risk group' learners

\begin{tabular}{|l|l|}
\hline Learner, the creative works & Excerption \\
\hline $\begin{array}{l}\text { Schoolgirl K. K. In the essay titled } \\
\text { 'My household choirs' wrote, }\end{array}$ & $\begin{array}{l}\text { There are 7 people in my family. Everyone is in charge of their } \\
\text { own household chores. When we work seamlessly and together we } \\
\text { are like clockwork, moving in one direction"; }\end{array}$ \\
\hline $\begin{array}{l}\text { Schoolgirl A. Z. In the essay titled } \\
\text { 'My household chores' wrote, }\end{array}$ & $\begin{array}{l}\text { "Every member of my family is hardworking and motivated. } \\
\text { Therefore, we have our own household chores and duties. I don't } \\
\text { have a lot of them, but I try to do stick to them and do them } \\
\text { responsibly...'; }\end{array}$ \\
\hline $\begin{array}{l}\text { Schoolgirl K. D. In the essay titled } \\
\text { 'My household choirs' wrote, }\end{array}$ & $\begin{array}{l}\text { "I help my mom, dad and brothers at home. I tidy up the rooms, } \\
\text { cook dinner. My parents are proud of me. It gives me the strength } \\
\text { to become a better version of myself..."; }\end{array}$ \\
\hline $\begin{array}{l}\text { Schoolboy P. D. In the essay titled } \\
\text { 'My household choirs' wrote, }\end{array}$ & $\begin{array}{l}\text { "My household chores include looking after my brother, helping } \\
\text { my grandmother in the garden. I like it most when my dad asks me } \\
\text { to help fixing his car in the garage. We talk about everything, he }\end{array}$ \\
\hline
\end{tabular}




\begin{tabular}{|l|l|}
\hline & tells me about how he served in the army..."; \\
\hline $\begin{array}{l}\text { Schoolboy A. A. In the essay titled } \\
\text { My household choirs' wrote, }\end{array}$ & $\begin{array}{l}\text { "I do some household chores. If I have time to do all the things that } \\
\text { I need to do, sometimes I might offer my help to mom, dad and } \\
\text { grandma...'; }\end{array}$ \\
\hline $\begin{array}{l}\text { Schoolboy M. A. In the essay titled } \\
\text { 'The beauty of the human soul: }\end{array}$ & $\begin{array}{l}\text { "It is the inner world of an individual that is his soul. You cannot } \\
\text { in actions, deeds, in interactions. Kindness, responsiveness, } \\
\text { sincerity, love and fidelity are some of the qualities that an } \\
\text { individual with a beautiful soul possesses. How can one see the } \\
\text { inner beauty of an individual judging by appearance? Only people } \\
\text { with a beautiful and kind soul conquer evil, hatred, give warmth to } \\
\text { everyone who is near them..."; }\end{array}$ \\
\hline $\begin{array}{l}\text { Schoolboy S. M. In the essay titled } \\
\text { 'The beauty of the human soul' } \\
\text { wrote, }\end{array}$ & $\begin{array}{l}\text { "I think that the true beauty of an individual is the inner beauty, his } \\
\text { soul, a kind heart. There must be more people of that sort, so that } \\
\text { the world could change for the better. One cannot be beautiful, in } \\
\text { whose heart sits anger, cruelty, envy, meanness, greed..."; }\end{array}$ \\
\hline $\begin{array}{l}\text { Schoolgirl Ts. V. In the essay titled } \\
\text { 'The beauty of the human soul } \\
\text { wrote, }\end{array}$ & $\begin{array}{l}\text { "A man beautifies his soul with good deeds. He looks after and } \\
\text { takes care of the nature, plants and animals. An individual is } \\
\text { adorned with a soul, not an appearance..." }\end{array}$ \\
\hline
\end{tabular}

Thus, we have summarized the targeted storytelling strategies in Self-cognition classroom that might be used in classroom as potentially capable of enhancing learning outcomes. The method features the choice of stories oriented towards the values of Love, Veracity, Right Behavior, Non-Violence, and Peace (inner harmony).

\section{Discussion}

The purpose of our study was to develop a targeted storytelling technique for risk group schoolchildren for curriculum-oriented moral education in Self-cognition classroom, diagnostics of schoolchildren for curriculum development, and pilot testing the curriculum in classroom. Currently, we are actively studying international practices in moral education. For instance, Kaur (2015) points out that 'In most studies on teaching strategies for curriculum-oriented moral education we found the following elements: problem-based learning, working in groups, discussions, and using subject topics incorporating moral issues, dilemmas and values'. There is other kind of moral education in the UK, the US, which are generalized, Halstead and Pike (2006), Joseph and Efron (2005). Finnish scholars Rissanen et al. (2018) speak about moral qualities of a teacher and teacher training for spiritual education: Teaching is a moral profession. It is a vocation that demands both a deep personal commitment and clear, rational principles; The moral dimension of teaching includes orientations to moral sensitivity, moral judgment, moral motivation, moral behavior, as well as teachers' professional ethics and values. Medves (2018) outlines that the teacher must, then, be capable of guiding open moral communication.

Our technique is by no means entirely new, yet it worthy of being used in classroom. The Conscientiousness Scales and the Method of Conscientiousness Analysis are easy to use. It should be noted that after receiving the diagnostics results, teachers are required to work with children on an one-to- 
one basis. Moreover, teachers are encouraged not to publicly voice low diagnostic results, and are required to treat them with sensitivity focusing on one-to-one work with learners. Although Medves (2018) argues that the true meaning of value only unfolds in public discourse, and not in inner, internalized and subjective reflections, which are limited by the self, we believe that the inner work of the learner is significant, and, in our opinion, it is possible to blend the methods. The diagnostics results, received by learners as part of a face-to-face feedback session may stimulate further thinking and inner work. Moreover, by doing so, teachers contribute to the development of the intrapersonal intelligence in schoolchildren.

\section{Conclusion}

Targeted storytelling techniques imply a well-structured set of activities and tools used for solving practical problems inherent to moral education. This includes a clear goal, procedures, diagnostics, sequence of actions, specific steps, and stages aimed at identifying the values in thoughts and deeds, and behavior of a child. We recommend that teachers use the Conscientiousness Scales, the Method of Conscientiousness Analysis as well as the targeted storytelling technique as easy to use diagnostics tools.

In the future, we plan to further direct our research interest towards the active use of both other diagnostic tools aimed at spiritual and moral development from the psychological science, and application of storytelling in children's writing activities with the identification of self-cognition values. For this, we have already developed the following new activities, 'Three shots', 'My hobby', launched the storyboard method, etc. It can be observed that changes are taking place in approaches in modern pedagogy, through a shift towards values and meanings, more precisely, towards self-actualization of a child by identifying learner values and meanings in what they do, how they live and how the learner-teacher discourse unfolds

\section{References}

Abu Nasr al-Farabi (2019). Dobrodetel'nyj gorod. Tom 1 [The Virtuous City. Volume 1]. International Abay Club.

Barskiy, F. (2017, 10 October). Definition and structure of narrative. https://narrlibrus.wordpress.com/2009/08/16/def-structure/

Berger, P. L., \& Luckmann, T. (1995). Social'noe konstruirovanie real'nosti. Traktat po sociologii znaniâ [The social construction of reality: A treatise in the sociology of knowledge]. Znanie.

Comenius, J. A. (2003). O vospitanii [About upbringing]. School press.

Dzhurinsky, A. N. (2016). Istoriâ pedagogiki i obrazovaniâ [History of pedagogy and education]. Yurayt.

Fedorova, S. V., \& Barcheva, A. A. (2017). Ispol'zovanietehniki storitelling v rabote s det'mi doškol'nogo vozrasta [Use of storytelling techniques in working with preschool children]. Young Scientist, 16, 515-518. https://moluch.ru/archive/150/42606/

Grigorovich, L. A. (2003). Pedagogika i psihologiâ [Pedagogy and psychology]. Gardariki.

Halstead, M., \& Pike, M. (2006). Citizenship and moral education: Values in action. Routledge.

Ilyin, Y. P. (2016). Psihologiâsovesti. Vina, styd, raskaânie [The psychology of conscience. Guilt, shame, remorse]. Publishing house Peter.

Ilyin, Y. P. (2001). Ėmocii $i$ čuvstva [Emotions and feelings]. Publishing house Piter.

Isaeva, Z., \& Taubayeva, S. (2000). Pedagogičeskij èksperiment [Pedagogical experiment]. Kazakh University.

Johnstone, B. (2016). 'Oral versions of personal experience': Labovian narrative analysis and its uptake. Journal of Sociolinguistics, 20(4), 542-560. https://doi.org/10.1111/josl.12192 
Joseph, P. B., \& Efron, S. (2005). Seven worlds of moral education. Phi Delta Kappan, 86(7), 525-533.

Jung, C. G. (2019). Psychology of the Unconscious: A Study of the Transformations and Symbolisms of the Libido. Routledge.

Jung, C. (2020). Arhetipy i kollektivnoe bessoznatel'noe [Archetypes and the collective unconscious]. AST Publishing House.

Kadyrova, R. G. (2012). The theory of narrative and narrative analysis in psychology. Vector of science of Togliatti State University. Series: Pedagogy\&Psychology, 2(9), 126-128.

Kaur, S. (2015). Moral values in education. IOSR Journal Of Humanities And Social Science, 20(3), 2126.

Konstantinov, N. A. (1981). Istoriâ pedagogiki [History of pedagogy]. Prosveshenie.

Kozachina, A. V. (2018). National model of interpretation of the concept "life" in Japanese pedagogical discourse (on the material of the "Course of moral education"). Actual problems of philology and pedagogical linguistics, 2(30), 24-32. https://doi.org/10.29025 / 2079-6021-2018-2(30)-24-32

Manerko, I. V. (2011). Spiritual and moral qualities of the personality of a serviceman of the modern Russian army: essence, features and directions of development (socio-philosophical analysis). (Doctoral Dissertation). Military university. https://www.dissercat.com/content/dukhovnonravstvennye-kachestva-lichnosti-voennosluzhashchego-sovremennoi-rossiiskoi-armii-s

Medves, Z. (2018). Education (Bildung) for Values. New Pedagogical Challenges in the 21st Century: Contributions of Research in Education, 73.

Mukazhanova, R. A., \& Omarova, G. A. (2016). Rol' učitelâ v programme nravstvennoduhovnogoobrazovaniâ «Samopoznanie» [The role of the teacher in the program of moral and spiritual education "Self-Cognition"]. Bobek NSPWC.

Mukazhanova, R. A., \& Omarova, G. A. (2013). Metodika prepodavaniâ samopoznaniâ v škole [SelfCognition Teaching Methods for Schools: Teacher's Guide]. Bobek NSPWC.

Mynbayeva, A., Anarbek, N., \& Yeseeva, M. (2016) Education and Spirituality in Kazakhstan: "Selfcognition" Metadiscipline Features and Methods of Teaching. The European Proceedings of Social \& Behavioural Sciences, 8, 154 - 161. https://doi.org/10.15405/epsbs.2016.05.16

Mynbayeva, A., Minash, A., \& Karabutova, A. (2019). Coaching methods in teaching self-cognition and enhancing methodical competencies of teachers. In icCSBs 2019-The Annual International Conference on Cognitive-Social, and Behavioural Sciences (pp. 112-123). Moscow. https://doi.org/10.15405/epsbs.2019.12.02.14

Novichkova, A. V., \& Vokresenskaya, Yu. V. (2014). Storitellingkak sovremennyj instrument upravleniâ personalom [Storytelling as a modern tool for personnel management]. Naukovedenie, 6. [Electronic resource]. http://naukovedenie.ru/

Omarova, G. A., Akhmetova, A. I., Abdrakhmanova, A. M., \& Bagadaeva, Z. A. (2016). Duhovnoe nasledie čelovečestva [Spiritual heritage of humanity. Methodological guide for teachers]. Bobek NSPWC.

Pak Su Chin (2007). Comparative analysis of the content of education in an elementary school of the Republic of Korea and Russia (Doctororal dissertation). Kuban State University. http://naukapedagogika.com/pedagogika-13-00-01/dissertaciya-sravnitelnyy-analiz-soderzhaniyaobrazovaniya-v-nachalnoy-shkole-respubliki-korei-i-rossii

Petrakova, T. I. (1999). Humanistic values of education in the process of spiritual and moral education of adolescents (Doctoral Dissertation). Institute of General Education. https://www.dissercat.com/content/gumanisticheskie-tsennosti-obrazovaniya-v-protsessedukhovno-nravstvennogo-vospitaniya-podro.

Petrakova, T. I. (2016). Duhovno-nravstvennoevospitanie škol'nikov v cennostnom kontekste sovremennogo obrazovaniâ [Spiritual and moral education of schoolchildren in the value context of modern education]. Yaroslavl Pedagogical Bulletin, 5, 15-21.

Podlasy, I. P. (1996). Pedagogika [Pedagogy]. Prosveshenie.

Polkinghorne, D. E. (1988). Narrative knowing and the human sciences. Suny Press.

Rissanen, I., Kuusisto, E., Hanhimäki, E., \& Tirri, K. (2018). The implications of teachers' implicit theories for moral education: A case study from Finland. Journal of Moral Education, 47(1), 6377 . 
Sopova, N. V. (2014). Formirovanie duhovno-nravstvennyh kačestv ličnosti staršeklassnika na osnove cennostnoj problemnoj $s$ [Formation of spiritual and moral qualities of a senior pupil's personality based on the value problem situation: Monograph]. Voronezh State Pedagogical Institute.

Starichenko, B. E. (2015). Professional'nyj standart i IKT-kompetencii pedagoga [Professional standard and ICT competence of a teacher]. Pedagogical education in Russia, 7, 6-15.

Suholentseva, E. N. (2013). Formirovanieduhovno-nravstvennyh kačestv molodeži sredstvami volonterskoj deâtel'nosti [Formation of spiritual and moral qualities of youth by means of volunteer activities]. Voronezh State Technical University Bulletin, 9(3-2), 197-200.

Teaching and Learning for a Sustainable Future (2018, 05 May). http://www.unesco.org/education/

Todorova, O. (2014). Storitelling kak innovacionnyj PR-instrument [Storytelling as an innovative PRtool]. Modern problems of science and education, 4, 610-619. https://www.scienceeducation.ru/pdf/2014/4/360.pdf

Trotsuk, I. V. (2004). Narrativ kak meždisciplinarnyj metodologičeskij konstrukt v sovremennyh social'nyh naukah [Narrative as an interdisciplinary methodological construct in modern social sciences]. Bulletin of the Peoples' Friendship University of Russia. Series: Sociology, 1 (6), 41-53.

Xiaoman, Z. (2006). Moral education and values education in curriculum reform in China. Frontiers of education in China, 1(2), 191-200. 